\title{
Work-Life Balance Among Expatriates
}

\section{NABIHAH SULAILI BINTI ABD MALEK, ZAITON HASSAN, SURENA SABIL}

\author{
Faculty of Cognitive Sciences and Human Development, \\ Universiti Malaysia Sarawak, 94300 Kota Samarahan, Sarawak Malaysia. \\ Corresponding author: hzaiton@unimas.my
}

\begin{abstract}
There are 90000 professional expatriates working in Malaysia and the number is projected to increase year by year. This creates a need to explore work-life balance among expatriates in Malaysia. In this study, qualitative research method was used, and the data was collected using interview guide as the instrument. Actual data was collected from five (5) international lecturers in a public university in Sarawak. The data was analyzed using content analysis. The finding revealed that workload and family support are main contributors to work-life conflict among expatriates while receiving better salaries, meeting new people and experiencing culture are the work-life enrichment factors. Expatriates use general adjustment and interaction to adjust better with their new environment. Hence, it is recommended for organizations to support expatriates through relevant activities to assist them to achieve work-life balance in a foreign country.
\end{abstract}

Keyword: Expatriates, work-life balance, work-life conflict, work-life enrichment, strategies

Copyright: This is an open access article distributed under the terms of the CC-BY-NC-SA (Creative Commons Attribution-NonCommercialShareAlike 4.0 International License) which permits unrestricted use, distribution, and reproduction in any medium, for non-commercial purposes, provided the original work of the author(s) is properly cited.

\section{INTRODUCTION}

Today's increasingly global business world is resulting in more organizations to be competitive and making their employees to work outside their home countries as expatriates. Thus, in this current scenario, performing international work is a norm. Hence, expatriation is becoming the most ordinary decision in a way to meet the need to stay in markets even though it is challenging. In response to the advancing of technology and competitive market, the demand for expatriate employees is growing quickly as it becomes increasingly necessary for organizations to become globally accepted in short and long-term (Beechler \& Woodward, 2009) Therefore, as Malaysia is gearing towards becoming an industrialized country from a developing one, it is opening its market towards globalization which will be beneficial for trade and services.

According to Bernama (2015), a bank survey has rated Malaysia as one of the top five (5) destinations for work satisfaction with 55 percent of expatriates saying they found their work more fulfilling since relocating. The inflow of expatriates into this country is to meet the demands of skilled and professional manpower in multiple fields and a continuity of inflow of expatriates in at least 10 years to come is expected. Hiring expatriates exposes Malaysia to the expertise of individuals from other countries. According to the statistics provided by Malaysia's Department of Immigration, the number of professional working expatriates residing in Malaysia is about 90, 000 (Department of Immigration, Malaysia, 2000). Generally, when an individual decides to become an expatriate, it does not only affect themselves but the overall situation. Even though expatriation is a challenging task, it is also undeniable that it has a positive outcome, which is work-life enrichment (Mäkelä \& Suutari, 2011). Hence, the rationale of this research is to observe expatriate's work-life conflict and enrichment in work and family domain while performing overseas tasks and their strategies in adjustment to achieve work-life balance.

Work-life balance issue is usually a challenge for expatriates and their families. A positive or negative outcome in work-life balance is related to the roles of partner and families as well (Caligiuri et al., 1998). According to Greenhaus and Buetell (1985) work-life conflict happens when there are internal conflicts happening due to pressure from work and family domains. Role overload and interference are two components in work-life conflict (Greenhaus \& Buetell, 1985). First, role overload can happen when the prescribed activities of multiple roles are too vast to be performed systematically due to limited time and energy. Interference occurs when there are difficulties in fulfilling the requirements of multiple roles with the presence of conflicting demands. This happens due to work and family activities that must be performed at the same time but in different physical locations (Greenhaus \& Beutell, 2000). Enrichment is experienced when there are positive affects across work and private 
life. Previous studies stated that positive experiences in one role will improve the quality of life in the other (Carlson et al., 2006). Enrichment may happen when for instance, the physical, social, capital and material resources acquired or developed in one role result in an improve performance and positively impact on another role (Greenhaus \& Powell, 2006; Carlson et al., 2006). For example, a positive effect traversing from the personal life to the work domain could be found in a situation when an individual is enjoying a wonderful weekend with family and the positive mood being carried into a greater motivation to deal with the jobs and thus increase their effectiveness.

To successfully fulfil the foreign assignment, it is important for expatriates to adjust themselves to new cultural contexts (Huang, Chi, \& Lawler, 2005). Thus, to be able to adapt well to the new environment, expatriates need to know general knowledge and importance of the new culture. For instance, the knowledge about the legal and economic systems, the rules of the foreign language, non-verbal communications as well as cultural values and religious beliefs will help the expatriates to study about the norms of the host nation and adjust better with the new environment. Adjustment is very important during expatriation because research has shown expatriates tend fail in their position if the expatriates do not adjust well to the host country (Caligiuri, 2000).

The specific objectives of this study are (1) to explore work-life conflict in work and family domain to achieve work-life balance among expatriates, (2) to identify the work-life enrichment in work and family domain to achieve work-life balance among expatriates and (3) to find out the strategies to achieve work-life balance among expatriates. The research questions are (1) What are the work-life conflict in work and family domains to achieve work-life balance among expatriates? (2) What are the work-life enrichment in work and family domains to achieve work-life balance among expatriates? (3) What are the strategies to achieve work-life balance among expatriates?

\section{MATERIAL \& METHOD}

This study utilized the qualitative approach. By using this approach, it allowed the researcher to explore the area of perception and factors. This approach will also emphasize on the understanding of a subject, in this case, the informants by exploring deeply and thoroughly on their words, reactions and records. Information is gathered from the informants to be used to help the researcher to find out the result in order to achieve the objectives of this research. The biggest advantage of using qualitative approach is that it allows the researcher to dwell deeply into understanding the experiences of expatriates in achieving work life balance.

Population refers to a group of people, events or things that the researcher is desired to know in-depth their study (Sekaran, 2000). The population for this study is focused on professionals working at a public university in Sarawak. The sample of this study is informants of expatriates who are international lecturers from different faculties. In qualitative research, there is no specific population and sample to be used. According to Taylor and Bogdan (1984), it is difficult to determine how many people should be interviewed in a qualitative research. It is acceptable to have a population between 5 to 25 samples (Creswell, 1998). Several informants of foreign lecturers have been selected as the subjects for this study. They were chosen based on one (1) criteria which were length of service and their work experience. Based on these criteria, the informants who have worked as expatriates for a range of six (6) to twelve (12) months were selected. The sampling technique used was purposive sampling. Purposive sampling is a technique at which a researcher samples a respondent with a purpose in mind. This technique helps in reaching the targeted sample quickly. The information obtained undergo a pre-test to ensure it is met with the expectation of the researcher.

In this research, the main instrument in collecting data was interview guide. This method helps us to gain unlimited data, the opportunity to learn and explore the topic in more depth, and researchers can be a flexible in certain circumstances when carrying out similar methods (Rusli, Hasbee, Azman, Sopian, \& Nur, 2014). In this interview guide, it consisted of four (4) sections in which section A was demographic questions. Section B consisted of warming up questions in order to build rapport between interviewer and interviewee while situational questions were asked to bring the interviewee into the research topic. Section $\mathrm{C}$ questions were asked to answer the research objectives. For section D, a closing question was asked to give the interviewee the opportunity to ask the interviewer any doubts about the research. The interview sessions were recorded for the purpose of this study.

Before the interviews, the researcher provided a letter of authorization from the faculty to conduct a study and the letter must be approved by the supervisor. Next, the researcher obtained approval from the targeted faculties and once it was approved, the researcher received a list of foreign lectures that have been targeted for this study. After that, the informants required confirmation through email asking the respondents' agreement to be interviewed. An appointment was made based on the suitability of both parties for the date, time and place to conduct the interview 
session when the agreement was reached. A consent form which was signed by each informant was also provided. It is important that form consent forms are provided to ensure there are no misunderstandings that occur during and after the interview. Therefore, before the interview session, the informants were briefed about the research topic and the purpose of the study being conducted by the researcher. The researcher also tried to reach the balance between speaking and listening during this session. All the information and important data that had been delivered by the informants were recorded. Information obtained from interviews with informants represent the primary source while the secondary sources involved the use of documentary sources such as books which are related to the training method and the use of the internet as an information support.

In data analysis, it is divided into four (4) parts which are secondary or relational analysis, primary analysis, content analysis and thematic analysis. In this research, the data was analyzed based on the interviews that were conducted by using content analysis. Content analysis is a method of categorization of verbal or non-verbal data for the purpose of classification, summarization and tabulation. In content analysis, deductive approaches were used where the researcher transcribed word by word (verbatim) from the informant's content. There are five (5) steps in conducting content analysis. First step was organizing the data. At this stage, the researcher transcribed the data and classified them into two which are structure and familiarizing. Second step was identifying the framework. Next was sorting the data into a framework. The fourth step was using the framework for descriptive analysis. In content analysis, transcribing the data may take a long time where the researcher needed to listen carefully to the recording that was made and translate the conversation and then encode the information. The information obtained is used to explain the work-life balance among expatriates.

\section{RESULTS}

There are five (5) informants involved in this research. The informants were male and female which are currently working as international lecturers at a public university at Sarawak. They are from various ages, countries, background of education and departments. Table 1 shows the summary of the informants.

Table 1 Informants Demographic

\begin{tabular}{|c|c|c|c|c|c|c|c|c|}
\hline Informants & Age & Gender & Religion & $\begin{array}{c}\text { Marital } \\
\text { status }\end{array}$ & Position & $\begin{array}{l}\text { Length of } \\
\text { service }\end{array}$ & Education & Origin \\
\hline 1 & 57 & Male & Islam & Married & $\begin{array}{l}\text { Associate } \\
\text { Professor }\end{array}$ & 12 years & $\mathrm{PhD}$ & India \\
\hline 2 & 52 & Female & Islam & Married & $\begin{array}{l}\text { Associate } \\
\text { Professor }\end{array}$ & 10 years & $\mathrm{PhD}$ & Indonesia \\
\hline 3 & 54 & Male & Islam & Married & $\begin{array}{l}\text { Associate } \\
\text { Professor }\end{array}$ & 10 years & $\mathrm{PhD}$ & Indonesia \\
\hline 4 & 39 & Male & Islam & Married & Lecturer & 3 years & Master & Bangladesh \\
\hline 5 & 32 & Male & Islam & Married & Lecturer & 5 years & Master & South Africa \\
\hline
\end{tabular}


Table 2 Identification on Work-Life Conflict Faced by The Expatriates In Family And Work Domain

\begin{tabular}{lllll}
\hline No & Questions & Domain & Findings & Informants \\
\hline $1 . \quad$ & Have you experienced any conflict in & & Workload & $1,2,3,4,5$ \\
& balancing your roles at work since you & Work & & \\
& started working as an expatriate? & Different Legislation & 4 \\
& & & Spouse and family support & $1,2,3,4,5$ \\
2. & Have you experienced any conflict in & & Childrearing & 4,5 \\
& balancing your roles at home since you & Family & responsibilities & \\
& & &
\end{tabular}

Table 3 Identification on work-life enrichment faced by the expatriates in family and work domain.

\begin{tabular}{|c|c|c|c|c|}
\hline No & Questions & Domain & Findings & Informants \\
\hline 1. & $\begin{array}{l}\text { Have you experienced any enrichment } \\
\text { in balancing your roles at work since }\end{array}$ & Work & Better salary & 1,2 \\
\hline & you started working as an expatriate? & & Career advancement & $3,4,5$ \\
\hline \multirow[t]{2}{*}{2.} & $\begin{array}{l}\text { Have you experienced any enrichment } \\
\text { in balancing your roles at home since }\end{array}$ & Family & New people and culture & $1,2,3,4,5$ \\
\hline & you started working as an expatriate? & & Better opportunities & 4 \\
\hline
\end{tabular}

Table 4 Identification on the strategies to achieve work-life balance among expatriates

\begin{tabular}{lllc}
\hline No & \multicolumn{1}{c}{ Questions } & Findings & Informants \\
\hline $\begin{array}{l}\text { In your opinion, what are the strategies } \\
\text { to achieve work-life balance among } \\
\text { expatriates? }\end{array}$ & General adjustment & 2,3 \\
& Interaction adjustment & $1,4,5$ \\
\hline
\end{tabular}




\section{DISSCUSSION}

From Table 2 above, in work domain, majority of the informants stated that workload is the main obstacle to achieve work-life balance. One of the informants mentioned that:

"Last semester was busy. Most of the time I'll be teaching and doing research. I came to my office at 7am and went back home at 9:30 pm. I was teaching at PPP, then running to teach SPSS at Faculty of Engineering then teaching Soft Skills here."

\section{(Informant 1)}

From this study, it shows that workload is one of the work-life conflict in expatriate's work domain. This finding is consistent with almost every study on work-life balance among expatriates (Shaffer et al., 2001), as long working hours and workload put a huge struggle on expatriates. In addition, the finding is also supported by a study by Shortland and Cummins (2007) where they stated that long working hours and lack of time for the family can cause physical or mental illness such as stress and emotional imbalance.

The above finding is also similar with a survey by ORC Worldwide (2007), which aimed at finding out the main stressors for expatriates. Workload and long working hours are the key areas in influencing work-life balance abroad. Two-thirds of expatriates reported they experienced longer working hours on an international assignment due to a higher number of responsibilities to meet their own working standards, and dealing with different cultural standards as to be successful in their career. Hence, a substantial amount of time is spent on business travels, telephone and conference calls, or meetings held outside normal business hours. Therefore, the expatriates reported feeling pressurized to work overtime because of their additional responsibilities compared with their local colleagues. Consequently, more than half of the expatriates felt overworked and overwhelmed.

Besides that, this study also found that different legislations also affect their work. One of the informants stated that:

"I can't drive my car to go to work since my license is not valid. The process to change it took approximately 3 months. I had to go to Kuala Lumpur since there's no embassy here in Sarawak."

\section{(Informant 4)}

This finding is similar with a previous study by Mäkelä and Suutari (2007). While working abroad, the work-life conflict was present due to different legislations, especially in the areas concerning maternity and annual leaves. This finding is consistent when one of their respondents decided to return to her home country due to birth of a baby. In short, workload and different legislations contribute to work-life conflict in work domain among expatriates.

In addition, the need to balance work and family life for a person working in their home country is somewhat difficult. But, for expatriates, when their work involves a family relocating to another country and having to adapt to new culture and customs, the negative impact on work-family balance is significant. Therefore, majority of the informants stated that lack of support from spouses and families are the contributing factor in work-life conflict among expatriates. As one of the informants stated that:

"It is quite challenging in the beginning. You know, when you come to the new country... you tried to build a network...making new friends. But I think it is more challenging when insufficient moral support is given. Especially from family members"

(Informant 1)

"Hmmm. Yes, I think my spouse is very supportive. I can say, if I don't get the support like how I received today, I will not be able to give my $100 \%$ commitment"

(Informant 2)

This finding is contradicting from the perspective of Segmentation theory, where it is suggested that both aspects of work and life are different entities and do not influence each other.. Spouse support is one of the important 
predictors in determining the successfulness of the assignments (Grant-Vallone \& Ensher, 2001). Cinamon (2006) stated that the low level of spousal support can raise a conflict in family domain. Thus, in a way to achieve worklife balance, these two domains cannot be separated as it will influence each other.

In addition, it is found very challenging to balance work and family when the working expatriates travel with their children. If a woman expatriate travels with a child or children, living in a new country, and far away from parents, families and peers appear to present considerable problems. As one of our informants said:

"Yes, I love my job. But since I travelled here with my wife and baby, we might experience tougher life compared to single expatriates."

(Informant 5)

Going on a foreign assignment is even much harder for expatriates with children. This goes hand in hand with Harris (2004) who has already stated that smaller children contribute more to a work family conflict than older ones. "My children are now grown-ups. They are so independent in taking care of each other even
my wife and I had to attend certain events until midnight"

(Informant 3)

For expatriates who have childrearing responsibilities, they find it difficult to find trustworthy childcare and good education. These two factors are often problematic for expatriates (Kollinger 2005a). As one of the informants stated that,

"I found myself so lucky that my wife is a full-time housewife. She is taking care of our baby here, so we don't have to look for a nanny for him."

(Informant 5)

In short, family and spouse are crucial and critical source of support for expatriates in dealing with work-related stress (Kraimer, Wayne \& Jaworski 2001) to gain enrichment while expatriating. As defined by Morris and Madsen (2005), enrichment theory is referring to the degree to which experiences from skills, abilities and values (contributory sources) or mood and satisfaction (emotional sources) enrich the quality of the other domain. In short, if an expatriate enjoys their work, most probably they will gain the same satisfaction to family domain. In addition, Linehan and Scullion, (2001) highlighted the importance of the spouse's support as well as the appreciation of the partner's career for a successful assignment and may therefore take pressure from the couple and reduce negative stress. In short, spouse and family support and childrearing responsibility contribute to worklife conflict in family domain among expatriates.

From Table 3 above, the positive effect on work and family domain were identified when expatriates experience a better lifestyle and salary, are able develop their skills through international work and have a wider opportunity to express themselves and find ease in their personal life. The process in developing a more competitive individual for their career is a positive opportunity for expatriates compared to if they had stayed in their home countries. From the above analysis, in work domain, the researcher found that better salary can be the factor of having worklife enrichment. One of the informants mentioned that:

“Enrichment? Hurm... I must say a better salary.”

(Informant 3)

Based on Greenhous and Powell model (2006), material resources such as better salary or gift, is one of the resources which can be classified as enrichment during expatriation. Besides, good quality housing, and opportunities to multitask are provided to an expatriate as solid resources in supporting expatriate's personal life spheres. The expatriates feel the benefit of being an expatriate is not only for themselves, but their families as well. One of the informants stated that:

"Currently, my daughter is pursuing her Master here. At my country, the university is quite far, and you need to travel 3 hours by trains."

(Informant 1) 
Trends in Undergraduate Research (2019) 2(1): e1-11

https://doi.org/10.33736/tur.1535.2019

"I am quite busy since I am teaching and doing PhD at the same time"

(Informants 4)

In short, better salaries and career advancement for expatriates and their family can be seen as indications of worklife enrichment during expatriation. Other than that, in family domain, these international assignments provide expatriates and their families with opportunities to meet new people and get to know new countries and cultures. One of the informants mentioned that:

"There are a lot of festivals and celebration here in Malaysia. Last year, I experienced celebrating Hari Gawai with my friends."

(Informant 5)

"I enjoy staying in here. I learned a lot of new cultures. My family too. Food is the best part above all. There's always something new that I've never try before. Like Umai, Ambuyat and Tebaloi."

(Informants 4)

This study was similar with the previous research done by Makela and Suutari (2011) as they stated expatriation is a positive step in career advancement or as an adventure providing expatriates with opportunities to meet new people and get to know new countries and cultures. Next, according to Expat Explorer report, (2016), one of the top three reasons why expats choose to move to Malaysia are opportunities to improve their quality of life. More than half of expats in Malaysia agreed that the overall quality of life is better and less expensive than in their country of origin.

"The quality of my country is very different from here in Sarawak. There (home country), they like honking harshly on the road. Busy roads every day and the working place is so far away. I can 't take taxi since it very expensive. But I can afford it here"

(Informants 5)

Ergo, from these findings, it shows that meeting new people and culture and better opportunities are the work-life enrichment in family domain among expatriates.

From Table 4 above, the researcher identified the strategies to achieve work-life balance among expatriates since it is not easy to start living in the new country. In order to enjoy the international assignments, expatriates need to handle the challenges well to make a better adjustment in their lifestyles. (Ward \& Rana-Deuba, 2000; Zakaria, 2000). Drawing from Black et al. (1991) model, there are 3 models of adjustment which are general adjustment, interacting adjustment and work adjustment.

General adjustment is the degree of comfort with non-work factors like housing environment, foods, language, transport, etc. Interaction adjustment is the comfort achieved when dealing with local nationals in both work and non-work situations. Shaffer and Harrison (2001) stated that the effective development in interacting with the host nations is coming from a good adjustment. This study is similar with the previous research done by Barhem (2008) in which there is a connection with expatriated behavioral competence in social interaction and language fluency to adapt better with local people. As mentioned by one the informants:

"Basically, Bahasa Melayu and Bahasa Indonesia are quite same. That makes me and family members adjust better here with local people."

(Informant 2)

From this study, it is consistent with the previous studies where it is a natural response when people are interacting in their native language. Thus, if expatriates can speak a certain language used in the host country fluently, it will help to adjust better with the local nations. It is proven because a study done by Ramalu, Rose, Uli, \& Kumar, (2010). did mention that language proficiency helps expatriates facilitated their interaction adjustment in the host country.

Malaysia is well-known for its diversity and because of this, most expatriates find it interesting to settle down in Malaysia. However, because the majority of Malaysians are Malays and they practice Islam, non-Muslim expatriates may find it challenging to adapt with the Muslim practises. But, knowing there will be a cultural 
difference between Malaysia and their home country, most of expatriates will ensure to respect the local customs and they find themselves be more sensitive towards the changes either in work or non-work environment. As Elashmawi (2001) stated, if an individual experiences problem to understand their own cultural values in effecting their behaviour, same cases will happen when they try to understand another person's behaviour. Thus, cultural clashes will happen. However, for informant 2, she found understanding Islamic religious restrictions is easier since she is a Muslim.

"Since I am a Muslim, it helps my family and me to adjust better here. There are a lot of masjid/mosque, activities for Muslim families and children as well as Islamic school."

(Informant 2)

"Ifeel just like home when celebrating Ramadhan in Malaysia. My family and I will go to nearby masjid at our housing area and performing the prayers. Same things we do at my country"

(Informant 5)

Adaption to live in a foreign nation such as housing, health care, and education facilities are known as general adjustment (Black and Stephens 1989). Besides, based on Bartol and Martin's (2000) cross-cultural management theory, most cases of expatriation will take 6 to 12 months to be able to make a better adjustment in a new country setting. Thus, a study by Fish (2005) ) stated that, in order for the expatriates to be better accepted by the local nations, they need to blend well with the cultural differences and applying it within the role of an expatriate and the structure of organization. This may help the expatriates to gain better acceptance by the local employees. Thus, an alternative to which these expatriates can prepare themselves with these adjustments is through orientation. Orientation is crucial in improving the skills and positive behavior to prevent cultural shock during performing the assignment among expatriates. One of informants claimed that he had difficulties in terms of searching for Halal food in the host cultural environment.

"The first time I came here, I was quite shocked when there are non-halal and halal restaurants operating side by side at Desa Ilmu. Because of that, I think, orientation should be done for us to know, where to get halal food with a genuine environment that we preferred."

(Informant 5)

One of informants also stated that he was having difficulties asking about directions with the locals.

'I was having difficulties during asking for direction with the local. During that time, my family and I were in the lift to grab our dinner. I was asking which floor I should go to get to the restaurant right... But they just nodded and smiled.'

(Informant 4)

When an expat is relocated to a new environment, they will often face many challenges. A supportive orientation from the organization that explains Malaysian cultures, languages, food, housing etc, can be a tremendous support system and best practices to help expatriates to adjust better to avoid pitfalls and misunderstanding. As one informant said,

"Orientation or cultural training in group will help us to adjust better. Because in group, we will meet and interacting with other expatriates and making new friends. I always think it is a good idea"

(Informant 2)

Richardson and McKenna (2002) further confirm that orientation from the host organization is important in showing the support from the organization itself. Orientation provides some free spaces for expatriates to make a better adjustment during their international assignment or if not, expatriates will tend to repatriate prematurely. 


\section{CONCLUSION}

This study has managed to gather information on the work- life balance among expatriates in Malaysia by using qualitative approach. Findings from this research acknowledge that expatriates in Malaysia face work-life conflict in handling workload and getting the support from their spouse and family. Better salaries and meeting new people and culture contribute to their work-life enrichment in work and family domain respectively. Moreover, expatriates found out that the use of general adjustment and interacting adjustment are helping them to adjust better in the new country. Thus, fundamental support and help from family, friends, organizations and HR practitioners are needed to assist expatriates to achieve work-life balance in a foreign country.

\section{ACNOWLEDGEMENT}

Assalammualaikum Warahmatullahitaala Wabarakatuh and greetings to all. First and foremost, Alhamdulillah to Allah The Most Gracious for giving me strength and motivation throughout the journey in completing this research. A big shout out to my lovely parents, Abd Malek Bin Sanat and Migawati Binti Atan for their solid support and never-ending love during my ups and downs. Not to forget, my siblings and partner for their encouragement and motivation. Without all of them, I would never be able to walk this journey successfully. I would like to deliver my huge thank you to my wonderful supervisor, Associate Professor Dr. Zaiton Binti Hassan for her advice and guidance from the beginning until the completion of this research. It is such an honor to have her as my supervisor. Heartfelt thanks also goes to the international lecturers which for their willingness to authorize me to conduct this research. My infinite thanks to all staff of the organizations who were involved in this study for the cooperation given. I am humbly asking for forgiveness in any flaws in this research. Finally, I hope this project can be beneficial to all. Thank you.

\section{REFERENCES}

Armstead, L. S. (2015). Balancing the life: A case study on single African American working mothers. Available from ProQuest Dissertations \& Theses Full Text: The Humanities and Social Sciences Collection. (1709243840). Retrieved from http://search.proquest.com/docview/1709243840?accountid=10359

Bernama (2015). Malaysia one of top 5 places for expatriates, survey finds. Retrieved from http:/www.mida.gov.my/home/2772/news/malaysia-one-of-top-5-places-for-expatriates-survey-finds/

Beechler, S. and Woodward, I. (2009), The global 'war for talent, Journal of International Management, 15 (3), pp. 273-85.

Black, J. S., \& Stephens, G. K. (1989). The influence of the spouse on American expatriate adjustment and intent to stay in Pacific Rim overseas assignments. Journal of management, 15(4), 529-544.

Caligiuri, P. M. (2000). Selecting expatriates for personality characteristics: A moderating effect of personality on the relationship between host national contact and cross-cultural adjustment. MIR: Management International Review, 61-80.

Caligiuri, P. M., Hyland, M. M., Joshi, A., \& Bross, A. S. (1998). Testing a theoretical model for examining the relationship between family adjustment and expatriates' work adjustment. Journal of Applied Psychology, 83(4), 598.

Carlson, D. S., Kacmar, K. M., Wayne, J. H., \& Grzywacz, J. G. (2006). Measuring the positive side of the workfamily interface: Development and validation of a work-family enrichment scale. Journal of vocational behavior, 68(1), 131-164.

Carlson, D. S., Grzywacz, J. G., \& Zivnuska, S. (2009). Is work family balance more than conflict and enrichment? Human Relations, 62(10). 1459-1486.

Cinamon, R. G. (2006). Anticipated work-family conflict: Effects of gender, self-efficacy, and family background. The Career Development Quarterly, 54(3), 202-215.

Department of Immigration Malaysia, (2000). Statistical Report Dated from 01/01/1999 to 31/12/1999. Kuala Lumpur: Immigration Department of Malaysia. 
Elashmawi, F. (2000, February 19). Cross-cultural negotiation. New Straits Times, 8.

Elashmawi, F., and Harris, P. R. (1993). Multicultural management: New skills for global success. Houston: Gulf Publishing Co.

Finegold, D., \& Mohrman, S. A. (2001). What do employees really want? The perception vs. the reality. Paper presented at the annual meeting of the World Economic Forum, Davos, Switzerland.

Fish, A. (2005). Assisting cross-border manager adjustment: Psycho-cultural and socio-cultural interventions. Personnel Review, 34(2), 225-245.

Foster, N. (2000). Expatriates and the impact of cross-cultural training. Human Resource Management Journal, 10(3), 68-78.

Frone MR. (2003). Work-family balance. In: Quck JC, Tetrick LE, editors. Handbook of occupational health psychology. Washington, DC: American Psychological Association; pp. 13-162.

Giacalone, R.A. \& Beard, J.W. (1994). Impression management, diversity and international management. American Behavioral Scientist, 37(5), 621-636

Greenhaus, J. H., \& Beutell, N. J. (1985). Sources of conflict between work and family roles. Academy of management review, 10(1), 76-88.

Greenhaus, J. H., \& Powell, G. N. (2006). When work and family are allies: A theory of work-family enrichment. Academy of Management Review, 31(1), 72-92.

Grant-Vallone, E.J., \& Ensher, E.A. (2001). An examination of work and personal life conflict, organizational support, and employee health among international expatriates. International Journal of Intercultural Relations, 25(3), 261-278.

Harris, H. (2004). Global careers: Work-life issues and the adjustment of women international managers. Journal of Management Development, 23(9), 818-832.

Huang, T.J., Chi, S.C., \& Lawler, J.J. (2005). The relationship between expatriates' personality traits and their adjustment to international assignments. International Journal of Human Resource Management, 16, 16561670.

Kraimer, M.L., Wayne, S.J. \& Jaworski, R.A. (2001). Sources of support and expatriate performance: The mediating role of expatriate adjustment. Personnel Psychology, 54 (1), 71-97

Lin, C.Y.Y., Lu, T.C., \& Lin, H.W. (2012). A different perspective of expatriate management. Human Resource Management Review, 22, 189-207.

Linehan, M., \& Scullion, H. (2001). European female expatriate careers: Critical success factors. Journal of European Industrial Training, 25(8), 392-418.

Lambert, S. J. (1990). Processes linking work and family: a critical review and research agenda. Human Relations, 43(3), 239-257.

Mäkelä, L., Känsälä, M., \& Suutari, V. (2011). The roles of expatriates' spouses among dual career couples. Cross Cultural Management: An International Journal, 18(2), 185-197.

Merriam, S. B. (1998). Qualitative Research and Case Study Applications in Education. San Francisco, CA: Jossey-Bass Publishers.

Morris, M. L., \& Madsen, S. R. (2007). Advancing work-Life integration in individuals, organizations, and communities. Advances in developing human resources, 9(4), 439-454.

Parker, P, \& Inkson, K. (1999). New forms of career: The challenge to Human resource management. Asia-Pacific Journal of Human Resources, 37, 76-85. 
Ramalu, S. S., Rose, R. C., Uli, J., \& Kumar, N. (2010). Personality and cross-cultural adjustment among expatriate assignees in Malaysia. International Business Research, 3(4), 96.

Richardson, J. \& McKenna, S. (2002). International experience and academic career: What do academics have to say? Personnel Review, 32(6), 774 - 793).

Shortland, S., \& Cummins, S. (2007). Work-life balance: Expatriates reflect the international dimension. Global Business and Organizational Excellence, 26(6), 28-42.

Starr, T.L., \& Currie, G. (2009). Out of sight but still in the picture: Short-term international assignments and the influential role of family. International Journal of Human Resource Management, 20, 1421-1438.

Stone, R.J. (1991). Expatriate selection and failure. Human Resource Planning, 14(1), 9-18.

Suutari, V. and Mäkelä, K. (2011), The career capital of managers with global careers, Journal of Managerial Psychology, 22 (7), 628-48

Tung, R.L. (1998). American expatriates abroad: From neophytes to cosmopolitans. Journal of World Business, $33(2), 125-144$

Tung, R.L. (1987). Expatriate assignments: Enhancing success and minimizing failure. Academy of Management Executive, 1(2), 117-125.

Van Erp, K.J.P.M., Giebels, E., Van der Zee, K.I., \& Van Duijn, M.A.J. (2011). Expatriate adjustment: the role of justice and conflict in intimate relationships. Personal Relationships, 18, 58-78.

Vromans, P, van Engen, M, Mol, S. (2013) Presumed cultural similarity paradox: expatriate adjustment and performance across the border or over the globe. Journal of Global Mobility, 1(2): 219-38.

Ward C. and rana-Deuba, A. (2000). Home and host culture influences on sojourner adjustment. International Journal of International Relations, 24, 291-306.

Wayne JH, Grzywacz JG, Carlson DS, Kacmar KM. (2007) Work-family facilitation: a theoretical explanation and model of primary antecedents and consequences. Human Resource Management Review, 17, 63-76

Zakaria, N. (2000). The effects of cross-cultural training on the acculturation process of the global workforce. International Journal of Manpower, 219, 492-510 